\title{
Thermal anomalies and fluid geochemistry framework in occurrence of the 2000-2001 Nizza Monferrate seismic sequence (northern Italy): Episodic changes in the fault zone heat flow or chemical mixing phenomena?
}

\author{
F. Quattrocchi ${ }^{1}$, R. Favara ${ }^{2}$, G. Capasso ${ }^{2}$, L. Pizzino ${ }^{1}$, R. Bencini ${ }^{1}$, D. Cinti ${ }^{1}$, G. Galli ${ }^{1}$, F. Grassa ${ }^{2}$, S. Francofonte ${ }^{2}$, \\ and G. Volpicielli ${ }^{2}$ \\ ${ }^{1}$ INGV-Roma, Via di Vigna Murata 605, 00143 Roma, Italy \\ ${ }^{2}$ INGV-Palermo, Via Ugo La Malfa 153, 90146 Palermo, Italy
}

Received: 4 June 2002 - Revised: 3 October 2002 - Accepted: 7 October 2002

\begin{abstract}
The paper discusses the correlation between the heating of shallow groundwater over a $10 \times 20 \mathrm{~km}$ wide area close to the town of Nizza Monferrato (Piemonte Region, Northern Italy) and the concomitant local seismic sequences during the period August 2000 - July 2001. The first seismic sequence started on 21 August 2000 with a $\mathrm{M}_{l}=5.2$ earthquake. Within few hours, the local authorities received calls alerting that the groundwater temperature rose from 10 to $30^{\circ} \mathrm{C}$ in many shallow wells. Our geochemical experimental data and the geological-seismotectonic framework do not allow the hypothesis of simple fluid mixing between the thermal reservoir of Acqui Terme and the Nizza-Monferrato shallow groundwater to explain the observed thermal anomalies. On the other hand, we invoke more complex processes such as frictional heating, mechano-chemistry, fault-valve mechanism, adiabatic decompression and hydrogeologically driven heat flow i.e., thermal effects due to variations of basin-scale permeability field. All these processes are able to transmit heat to the surface and to generate a transient incremental heat flow better than the mass transfer occurring typically when fluids from different reservoirs mix.
\end{abstract}

\section{Introduction}

In the last two decades major research on fluid geochemistry applied to seismotectonics have been focussed to the socalled "earthquake prediction research". This research identified a lot of precursory phenomena, constrained by several and widespread experimental observations as well as time series. Despite the huge work done on this field, the debate about earthquake prediction reliability is still open (Geller, 1997; Geller et al., 1997; Sornette, 1999; Wyss, 1997;

Correspondence to: F. Quattrocchi (quattrocchi@ingv.it)
Bernard, 2001), mostly as a consequence of the wrong conceptual approach used up to date and of the Self-Organised Critical (SOC) models (Bak and Tang, 1989; Geller et al., 1997). In any case, new experimental data and geochemical monitoring networks have to be strongly improved and validated (Quattrocchi et al., 2000 b; Zanzari et al., 2001; Galli et al., 2002), stressing the importance of a detailed knowledge of the "specific transients behaviour" of each studied area. Geochemical and geophysical networks should be exploited collectively by a multidisciplinary task-force that would be responsible for selecting seismogenic segments already recognised by paleo-seismological and seismic hazards studies (Gurrieri et al., 1984; EC projects Geochemical Seismic Zonation, Corinth Rift Laboratory 1996-2002; Quattrocchi et al., 1999; Quattrocchi, 1999; Salvi et al., 2000; Favara et al., 2001a, b). Only recently the importance to study the stress-strain and the associated pore-pressure cycles has grown enough (Sibson, 1992; Hickman et al., 1995; Teisserye and Majewski, 2001; Ingebritsen and Sanford, 1998). It contributed to shift the attention from "earthquake precursors" to "crustal-fluids transients" (Quattrocchi, 1999; Bernard, 2001). Following this approach, all the earthquake-related observed processes are analysed in a new, broader perspective of "transient" phenomena. In particular, "fluid transients" (geochemical and hydrological) have been frequently reported and possibly revisited (Thomas, 1988; Roeloffs, 1988; Ben-Zion et al., 1990; Igarashi et al., 1995; Toutain and Baubron, 1999).

In this paper we describe other transient phenomena besides those described by Bernard (2001) proposing intriguing "heat flow and mechano-chemical transients" (Smith and Chapman, 1983; Brune et al., 1969; Sornette, 2001; Ingebritsen and Hayba, 1994; Ingebritsen and Sanford, 1998; Teisseyre and Majewsky, 2001; Beardmore and Cull, 2001). We discuss a particular case history of "fluid temperature 

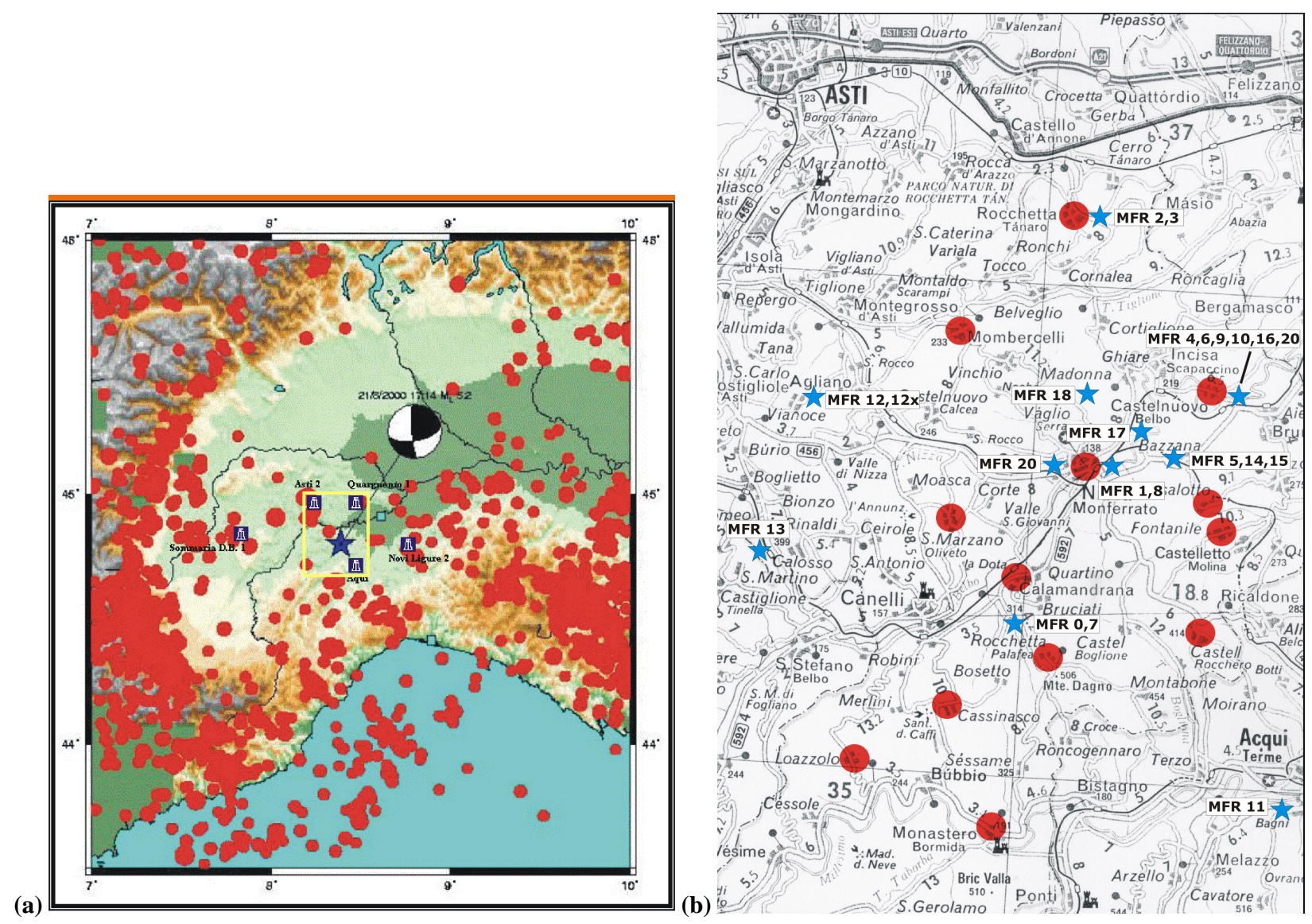

Fig. 1. (a) INGV recorded seismicity in the last two decades (red circles). Focal mechanism reworked by the INGV Mednet network (unpuplished). Blue star indicates the epicentre of the 21 August 2000 earthquake. AGIP-ENI oil wells in the area surrounding the epicentral area are shown too. Yellow square indicates the area affected by thermal anomalies in the shallow aquifers corresponding to (b), where the affected localities are reported as red circles and the INGV sampling sites as blue stars.

transient" associated to natural seismicity in the Tertiary Piemonte Basin (hereafter "TPB", Piemonte, Northern Italy), and we try to explain the observed phenomena, considering the seismotectonic framework too.

\section{The heating of groundwater in the occasion of the Nizza-Monferrato seismic sequence}

Starting from the first hours after the 21 August 2000 earthquake $\left(M_{l}=5.2\right.$, Fig. 1a) recorded at 19:14 LT in the vicinity of the town of Nizza Monferrato (lat. $44.80^{\circ} \mathrm{N}$, long. $8.39^{\circ} \mathrm{E}$ ), calls were received by the public authorities alerting that the groundwater temperature rose approximately from $10^{\circ} \mathrm{C}$ to $30^{\circ} \mathrm{C}$ in many shallow wells throughout the epicentral area (Fig. 1b, red circles sites). The maximum temperature increase was recorded near the village of Incisa Scapaccino. The alignment of the anomalous temperature sites was found to strike generally NNE-SSW. The temperature increase warnings came from a wide area and continued for the duration of the seismic sequence, which was discontinuous and terminated with a moderate magnitudo event $\left(M_{l}=4.6\right)$ on July 2001. At the time of writing (May 2002) some wells remained anomalously warm. In certain localities both seismic events were felt and rumbles were heard by the population still today (as on 24 May 2002). Geochemical surveys were conducted in successive stages starting in November, 2000, while the water temperature were measured at intervals by the Piemonte Region authorities (unpublished internal report). Unfortunately, continuous monitoring stations able to record water temperature and geochemical-hydrogeological parameters are still lacking in the study area.

To the South of the area affected by the August 2000 main shock a thermal reservoir is present at a depth of approximately 3 to $5 \mathrm{~km}$. The main spring is called Acqui TermeBollente, and its temperature has been as high as $70^{\circ} \mathrm{C}$ in the past century (current average temperature $58^{\circ} \mathrm{C}$ ). This spring has recently been studied by Marini et al. (2000), and previously by Dominco et al. (1980) and by Bortolami et al. (1982, 1983, 1984). Therefore, the early and simplest hypothesis was that shallow cold groundwater become hot on the occurrence of the earthquakes, simply as a consequence of a mixing with the hot reservoir fluids of Acqui Terme due to fractures and permeability field modifications on regional scale, associated to the $M_{l}=5.2$ main event. However, as 

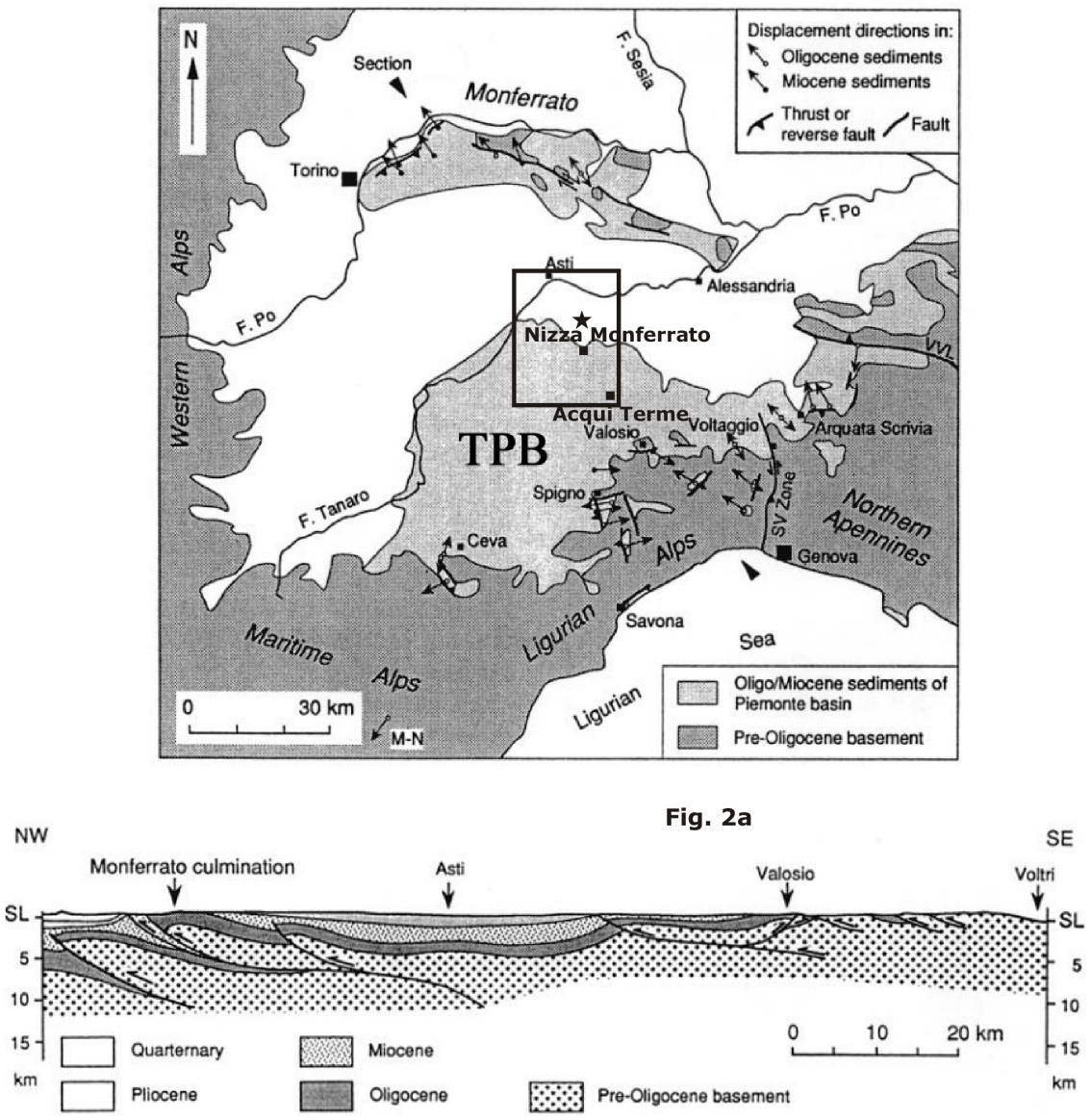

Fig. 2b

Fig. 2. (a) Kinematic study of the Tertiary Piemonte Basin (TPB), with the arrows indicating the hypothesises direction of movement. The arrows with double head indicate the uncertainty in the main translation direction. The points where the arrows start indicated the location of the outcrops studied by Hoogerduijn et al. (1991). SVR= Sestri-Voltaggio Zone; VVL=Villavernia-Varzi Line; M-N = translation direction hypothesized in the Miocenic Flysch deposits of the Marittime Alps. The arrows indicate the location of the profile shown in (b) being reconstructed after Cassano et al. 1986 (modified from Hoogerduijn et al., 1991).

discussed below, the geochemical experimental data seem to exclude this explanation.

\section{The 2000-2001 Nizza Monferrato seismic sequence in the TPB seismotectonic and geological framework}

The seismic sequence of August $2000\left(M_{\max }=5.2\right)$ and July $2001\left(M_{\max }=4.6\right)$ occurred within the TPB (Figs. 1 and 2) where the thickness of Tertiary sediments was inferred to be around $3-4 \mathrm{~km}$, with maximum values in the AstiAlessandria depo-center as highlighted by the AGIP reflection seismic surveys (Biella et al., 1987; Miletto and Polino, 1992). The first seismic sequence was characterised by 13 foreshocks at shallow depth and around 60 aftershocks, while the July 2001 sequence was characterised by approximately 20 events. Two different seismogenic structures have been inferred by Massa et al. (2002), one shallow $(0-3 \mathrm{~km})$ and one deep $(14-16 \mathrm{~km})$. The focal mechanisms of the above mentioned August, 2000 Nizza Monferrato main shock may be associated to a N50E strike-slip movement (Massa et al., 2002), quite different from the INGV preliminary result (Mednet INGV Network, unpublished data, Fig. 1). In the past, this area was characterised by an effective lack of historical events and by an almost total seismic quiescence (1369 MCS VII event and 1952 MCS VII event, see INGV Cata$\log$ ). Moderate magnitude event occurred in 1982 became $10 \mathrm{~km}$ to the west of the area of recent activity (Cattaneo et al., 1997).

While searching for the possible seismogenic structure, we considered the geophysical integrated analysis of Cassano et al. (1986) and of Miletto and Polino (1992). They stress the buried Villavernia-Varzi Line (hereafter "VVL", after Cassinis, 1986; Gelati et al., 1977, see Fig. 2). The minima Bouguer gravity anomaly values and the magnetic anomalies of Monferrato-Asti are associated with an important deflection of the Moho and with an abrupt deepening of the basement, resulting in a crustal thickening of $55 \mathrm{~km}$ un- 
der the Westward continuation of the VVL feature (Losecke and Scheelke, 1978; Gunther and Reutter, 1978; Armando et al., 1984; Arca and Beretta, 1985). At surface, the Western Monferrato area is characterised by N-S trending thrust faults affecting the Middle Miocene clays at multiple localities. Reflection seismic and gravimetric data would indicate that NW-SE trending vertical faults located in the Eastern Monferrato sector of TPB are connected at depth to a SW dipping detachment plane, rooted in the vicinity of Asti (Cassano et al., 1986). In essence, this complex area is located at the boundary between Alps and Apennines (Elter and Pertusati, 1973; Cassinis et al., 1986; Laubscher, 1988; Miletto and Polino, 1992; Bozzo et al., 1992) and it is not easy to establish genetic links between the known deep structures and the 2000-2001 seismic sequence sources.

From an hydrogeological point of view the TPB sedimentary succession is essentially impermeable. The regional shallow stratigraphic series $(0-3 \mathrm{~km}$ depth) comprises at its base the Serravalle Sandstones, the Molare Conglomerates, and, of particular interest in the epicentral area, the Gessoso-Solfifera Formation (Gypsum-Anhydrite strata, Sturiani, 1975) followed upwards by the Cassano Spinola Conglomerates, by the Lugugnano Clays and by the Asti Sands. The deepest reservoir is represented by the Triassic- Jurassic limestones and dolomites, hosting the NaCl-type hot reservoir of Acqui Terme described by Marini et al. (2000), but it does not crop out in the epicentre area. Several elements (Marini et al., 2000) suggest the presence of hydrocarbons or hydrocarbon source rock at depth under the discontinuous hydrogeological bodies near the surface, where the shallow wells, which become warm during seismic activity are located.

\section{Methods}

Seismic data have been gathered by the INGV seismic monitoring network, working in connection with the Genoa University local seismic network (Massa et al., 2002). Guided by local authority information, we sampled 26 groundwater sites, selecting wells affected by the temperature anomaly, some nearby wells for comparison and all the thermal and mineral springs inside this sector of the TPB, even if they were located relatively far from the thermal anomalies (Acqui Terme and Agliano Terme sites). We measured in the field temperature, $\mathrm{pH}$, redox potential, electrical conductivity, alkalinity and ${ }^{222} \mathrm{Rn}$ dissolved in groundwater (Mancini et al., 2000). Ionic chromatography (DIONEX Mod. 500 DX) was used to analyse $\mathrm{Ca}, \mathrm{Mg}, \mathrm{Na}, \mathrm{K}, \mathrm{Li}, \mathrm{SO}_{4}, \mathrm{Cl}, \mathrm{F}, \mathrm{NH}_{4}$, $\mathrm{NO}_{3}$, while an ICP-MS Perkin Elmer Mod. 610 was used for $\mathrm{B}, \mathrm{SiO}_{2}, \mathrm{Fe}, \mathrm{Mn}, \mathrm{As}, \mathrm{Br}, \mathrm{Sr}, \mathrm{Sb}, \mathrm{Hg}$ (ENEA lab. AMB TEIN CHIM). Nine samples were selected especially for $\delta^{13} \mathrm{C}$ analyses (McCrea, 1950). Moreover, dissolved gases were analysed by gas chromatography and by He mass-spectrometer (Capasso and Inguaggiato, 1998). (a)

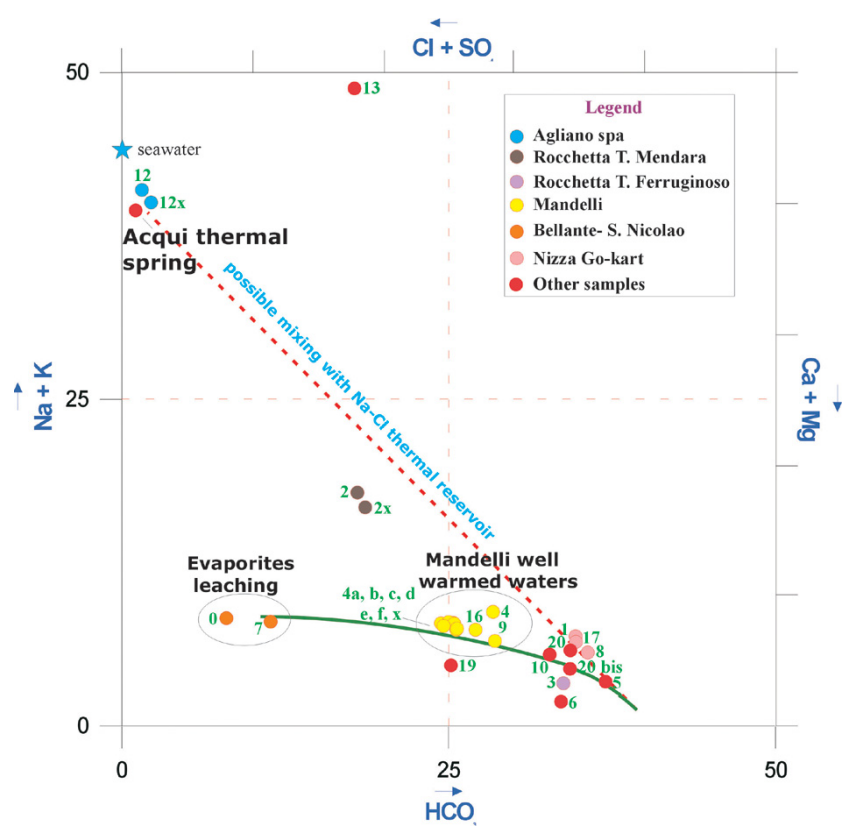

(b)

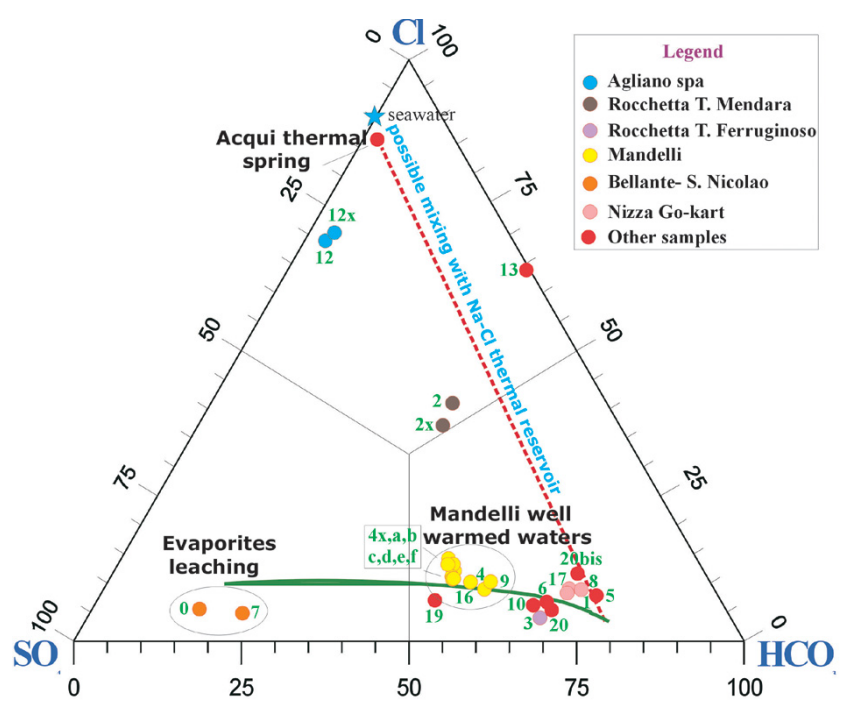

Fig. 3. (a) The Ludwig-Langelier diagram and (b) anions triangular diagram of the sampled waters. For the lines see the text.

\section{Results}

5.1 Water rock interaction processes throughout the NizzaMonferrato-Acqui Terme sector of TPB

The Ludwig-Langelier diagram an the main anions triangular diagram (Figs. 3a and b) show different groundwater families. In particular we focus our attention to the chemistry of groundwater affected by the thermal anomalies (MFR 1, 8 and 17, MFR 4, 4-X, 4-A, 4-B, 4-C, 4-D, 4-E, 4-F, 9, 16). Samples MFR 4, 4X-F, MFR 9 and 16 are those affected by the noteworthy water temperature variations from 10 to 
$30^{\circ} \mathrm{C}$, returning to normal temperature values approximately 4 months after the main shock These samples are not located along a mixing line (red line in Figs. $3 \mathrm{a}$ and $\mathrm{b}$ ) toward the Acqui Terme hot spring chemistry $\left(\mathrm{Na}-\mathrm{Cl}-\mathrm{SO}_{4}, \mathrm{~T}=70.2^{\circ} \mathrm{C}\right.$, Cond. El. $=4.00 \mathrm{mS} / \mathrm{cm}$ ), as expected by the first hypothesis, but they are shifted towards the sulphate earth-alkaline chemistry (green line also in Figs. 3a and b) which is typical of the groundwater leaching the Gessoso-Solfifera Formation (MFR 2, 2-X and mostly the MFR 0-7, Bellante S. Nicolao Well, $5 \mathrm{ppm}$ of $\mathrm{H}_{2} \mathrm{~S}$ in solution). Furthermore, the almost constant salinity values observed in these waters, rule out the hypothesis of contribution of the Acqui Terme reservoir in the warmed waters. On the other hand, groundwater that did not change temperature (MFR 3, 5, 6, 10, 19, 20 and 20 bis, with temperature $\leq 16^{\circ} \mathrm{C}$ ) continued to remain typically bicarbonate earth-alkaline. Besides the Acqui Terme spring, the Agliano Terme site is another possible "end-member" in the area, being a strongly mineralised cold spring $\left(13.6^{\circ} \mathrm{C}\right.$, $12.91 \mathrm{mS} / \mathrm{cm}$ ), probably representing the expression at surface of a prolonged leaching of the Asti Sands formation in presence of Messinian evaporites $\left(>15 \mathrm{ppm}\right.$ of $\mathrm{H}_{2} \mathrm{~S}$ resulting from the reduction of $\mathrm{SO}_{4}$, as explained in Quattrocchi et al., 2000 a). Differently, the MFR 13 Salto Valley artesian gas-rich well (main features: $12.5^{\circ} \mathrm{C}$, low water flow rate, presence of $\mathrm{CH}_{4}$ up to $86 \% \mathrm{v} / \mathrm{v}$ and $23 \mathrm{cc} / \mathrm{l}$ as dissolved phase, $\mathrm{NH}_{4}$-rich) is probably linked to clay sediments rich in organic matter at shallow depth.

The $\delta^{13} \mathrm{C}_{\mathrm{TDIC}}$ composition is almost uniform throughout the area, ranging between the typical composition for limestones $(-3 \% o \div+3 \%$ ) and the biogenic origin $(<-20 \%)$, falling mostly in the organic range. The Acqui Terme site exhibits the most negative values (-20) compatible with an organic composition of carbon, as hypothesised also by Marini et al. (2000). The Salto Valley emulsion exhibits a C isotopic composition $(-3.9 \%$ ), anomalous within the analysed population, and seems to be pertinent to the deep limestone dominia.

Minor and trace elements analyses confirmed the hypotheses suggested by the main elements chemistry: B is enriched in the groundwater leaching the deep reservoir (Acqui Terme) and the Messinian evaporites. Br derives mainly from leaching of marine sandstones. While $\mathrm{Sr}$ can be related to the interaction with the Gessoso-Solfifera Formation. Fluorine is enriched in the samples that come in contact with organic matter (MFR 11, 12 and 13). The heated groundwater are not enriched in $\mathrm{B}, \mathrm{Li} \mathrm{SiO}_{2} \mathrm{Sr}$ and $\mathrm{Br}$, confirming again the lack of the hypothesised mixing with regional hot waters. Also ${ }^{222} \mathrm{Rn}$ was found very low, confirming the absence of a fluids convection regime in the epicentral area as a whole (Quattrocchi et al., 1999). The lack of $\mathrm{CO}_{2}$ input in groundwater, confirmed also by the dissolved gases analyses, is in agreement with the very low levels of ${ }^{222} \mathrm{Rn}$ in groundwater and can be explained also by the presence of abundant $\mathrm{CO}_{2}$ capturing $\mathrm{Ca}-\mathrm{Mg}$ silicates in the rocks underlying the area (ophiolites and ophiolites-derived, Goff et al., 1998). The $\mathrm{N}_{2}$ and $\mathrm{CO}_{2}$ contents dissolved in the waters are only slightly above the Air Saturated Water conditions.

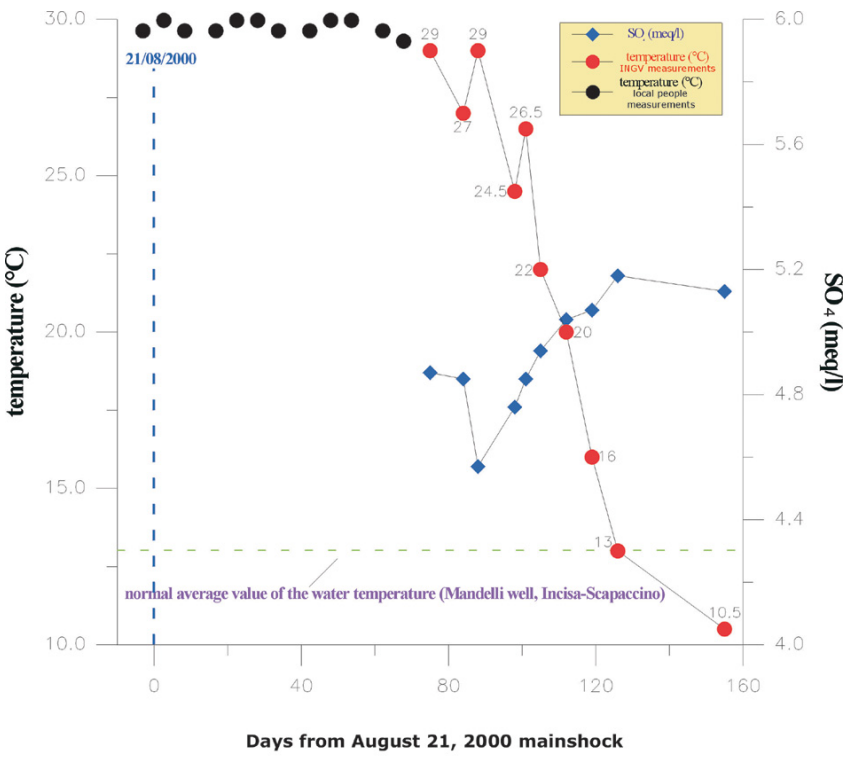

Fig. 4. Temporal trends of groundwater temperature and $\mathrm{SO}_{4}$ at the Mandelli Well (Incisa Scapaccina), the most warmed groundwater in this study, in concomitance of the seismic sequence of August 2000.

The dissolved gases analyses pointed out the presence of two main groups: the first one where $\mathrm{CO}_{2}$ is the prevalent phase (MFR 5, 6, 8, 9, 10) and the second one where $\mathrm{N}_{2}$ is prevalent (MFR 7, 11, 12, 13), with variable $\mathrm{CH}_{4}$-enrichments. The first group includes hot and cold waters with a calciumbicarbonate chemistry. The highest $\mathrm{CO}_{2}$ content was found in the warmed shallow groundwater. Anyway, here the $\mathrm{CO}_{2}-$ $\mathrm{CH}_{4}$ anomaly is really slight.

By using the Phreeqc software we calculated the saturation indexes of some main mineral phases for all the collected samples. As expected, the warmed groundwater reached the over-saturation with respect the pure carbonate phases, while only the Acqui Terme sample is over-saturated with respect to the Fluorite. The Factor Analysis, performed on 17 representative samples and 30 variables, summarises the main water-rock interaction processes in the area, clustering in the main factor the parameters of both the leaching of Messinian evaporites $\left(\mathrm{SO}_{4}, \mathrm{Ca}, \mathrm{Mg}\right)$ and of the marine sediments $(\mathrm{Na}$, $\mathrm{Cl})$. On the other hand, a second factor clusters the parameters linked to the organic matter $\left(\mathrm{F}, \mathrm{B}\right.$ and $\left.\mathrm{NH}_{4}\right)$ represented mainly by the Salto Valley MFR 13 sample. The third factor isolates the temperature with alkaline $\mathrm{pH}$ as well as $\mathrm{B}$, $\mathrm{Li}, \mathrm{SiO}_{2}$ and As being elements mobilised in hydrothermal conditions.

\subsection{Temporal trend during the main seismic sequence}

Even if the geochemical time series are very scarce compared to the macroscopic widespread information about the anomalous temperatures, it is possible to analyse the available longterm time-series of the warmest groundwater (Mandelli Well, $10 \mathrm{~m}$ deep, MFR 4, 4X-F and MFR 9 and 16, Fig. 4). It 
is worthy of note that the temperature decrease was simultaneous to a slight increase of the sulphate component. It seems that the shallow aquifer was progressively affected by a rising $\mathrm{Ca}-\mathrm{SO}_{4}$ component, after the heat source dissipation suggesting a link between the temperature variation and the Gypsum-Anhydrite phases transition equilibrium. Anyway, the available data are scarce and a future monitoring is strongly required.

\section{Discussion and conclusions}

The following main factors are considered important:

1. the alignment of the anomalous sites is mainly NNESSW, more or less corresponding to a well-known regional fault system which could be correlated to the possible focal mechanism of Massa et al. (2002);

2. the thermal anomalies affected very shallow and small water bodies (able to be warmed suddenly) and the overall permeability of the shallow series is low;

3. the warmed waters exhibited only slight differences with respect to the nearby heat-unaffected waters and the observed geochemical variations were found very slight compared to the temperature changes as a whole (up to $30^{\circ} \mathrm{C}$ ). A slight input of dissolved gases in the warmed water, consisting mostly of $\mathrm{CO}_{2}$ and $\mathrm{CH}_{4}$ was observed too;

4. the new experimental geochemical data seem to exclude a mixing with the Acqui Terme reservoir in concomitance of the seismic events;

5. the temperature variation is inversely correlated with a slight $\mathrm{SO}_{4}$ input at the main warmed well, suggesting a link between the Gypsum-Anyhdrite phases-transition equilibrium and the observed temperature variation.

All these experimental evidences are strongly important for the final comprehension of the observed phenomena. On the other hand, the following geological and seismo-tectonical considerations are also particularly important:

6. an almost strike-slip shallow earthquake occurred after a very long period of quiescence and the basement is affected by very complex thrusts and strike-slip transverse near-vertical faults;

7. the Gessoso-Solfifera Formation could be site of fast exothermic reactions or phase transitions also linked to stress variations (i.e. mechano-chemistry process, Sornette, 2001).

We are strongly convinced that the widespread thermal anomalies are strictly connected with the recorded seismicity. We hypothesise, considering the above constraining evidences, that the thermal variations observed in the small and shallow water bodies are linked to:
- a conductive heat input rather than a mass transfer in the vicinity of the activated fault, due to frictional heating processes (Scholz et al., 1979; Barton and England, 1979; Scholz, 1980; Lachenbruch and Sass, 1980; Sibson et al., 1980, 1982a, b; Molgard and England, 1990; Teisseyre and Majewski, 2001), lacking the conditions of the heat flow paradox (Brune et al., 1969; Lachenbruch, 1970, 1980; Henyey and Wasserburg, 1971; Lachenbruch and Sass, 1980; Lachenbruch et al., 1994; Hickman et al., 1995), as a consequence of the presence in the Monferrato area of quiescent, shallow and vertical strike-slip faults. The main relation we recalled is: $Q_{f}=d \times u \times \sigma f$ (from Beardmore and Cull, 2001), where $\mathrm{d}$ is the distance top-bottom of the fault (around $1 \mathrm{~km}$ for the Nizza Monferrato $M_{l}=5.2$ earthquake), $u$ is the slip velocity along the fault $\sigma_{f}$ is the stress along the fault (Molnar and England, 1990). The structural conditions and the peculiar source of the seismic sequence could be sound to generate frictional heat flux $Q_{f}$ at surface.

- Episodic exothermic reactions and phase transformations linked to the earthquake preparation processes as well as to the coseismic stress-drop are recalling the mechano-chemistry mechanism (Gilman, 1995, 1996; Sornette, 2001). In the case of the Monferrato area we hypothesise that these reactions occurred in the shallow strata, mostly inside of the Gessoso-Solfifera Formation, the Lucugnano Clays and within underlying, hyrocarbons-rich sedimentary bodies. This process developed a certain $Q_{m}$ (Sornette, 2001). We are recalling the hydratation-dehydratation reaction of the $\mathrm{Ca}-\mathrm{SO}_{4}$ phases (Mac Donald, 1953; Heard and Rubey, 1966; Quattrocchi et al., 1999). The main exothermic reaction is: $\mathrm{CaSO}_{4} \cdot \mathrm{H}_{2} \mathrm{O}=\mathrm{CaSO}_{4}+\mathrm{H}_{2} \mathrm{O}\left(\Delta \mathrm{Hr}=4 \times 10^{-3}\right.$ cal). Another possible reaction is the phase transformation Andalusite $\rightarrow$ Kyanite $\left(\mathrm{Al}_{2} \mathrm{SiO}_{5}\right.$ phases, with heat development of $6.12 \mathrm{kJKg}^{-1}$ ).

- Thermal effects $\left(\Delta Q_{f}\right)$ due to hydrogeologically driven heat flow on a basin scale (Smith and Chapman, 1983), as a consequence of modifications in the permeability and stress fields during the ongoing seismic sequence, may be co-responsible of the anomaly.

- Adiabatic-isoenthalpic decompression at depth affecting also the surface: this process could be triggered by the stress-drop and by the shock-wave in the vicinity, resulting in a heating of geologic fluids (Ramsber, 1971; Waldbaum, 1971; Wood and Spera, 1984). The main parameter governing this process - the Joule-Thompson coefficient - is negative (heating the fluids, $+\Delta Q_{a d}$ ) mostly for salty solutions (as found in the Salto Valley shallow aquifer) and for high bulk frictional coefficient $\left(C_{f}\right)$, namely throughout impervious sediments.

- An episodic vapour input, accompanied by an input of volatile elements (including the observed $\mathrm{CH}_{4}$ ), as a 
consequence of a fast fault-valve mechanism episode (Sibson et al., 1975; Nur and Walder, 1992; Quattrocchi, 1999; Brown, 2000). It is the process less constrained by our data and by the geologic framework.

Numerical modelling and more experimental data at detailed scale may confirm the inferred hypotheses.

Either the frictional heating, or the earthquake thermodynamics and mechano-chemistry processes are very intriguing to study crustal fluids transients and possibly earthquake precursors. They introduce an extremely interesting topic, opening a sound field of research of fluid geochemistry applied to seismotectonics.

Acknowledgements. We are grateful to the Nizza-Monferrato $\mathrm{Mu}-$ nicipality and in particular to the Environment-Urbanistic Assessorat, Dr. Perazzo and to the Piemonte Region, namely to Dr. Coccolo and Dr. Lazzari. Thank also to Dr. Ferrero, of the local Metereological Observatory and to Dr. Pozzo for the information during the sampling. We are grateful to Dr. C. Cremisini and Dr. Angelone to make available the ICP-Mass of the ENEA AMB TEIN CHIM Laboratory for minor-trace elements analyses.

\section{References}

Armando, E., Bozzo, E., and Lanza, R.: L'anomalia magnetica di Asti, Mem. Soc. Geol. It., 29, 35-41, 1984.

Bak, P. and Tang, C.: Earthquakes as a self-organised critical phenomenon, JGR, 94, 15 635-15 637, 1989.

Barton, C. M. and England, P. C.: Shear heating at the Olympos (Greece) thrust and the deformation properties of carbonates at geological strain rate, Bull. Soc. Geol Am., 90, 483-492, 1979.

Beardmore, G. R. and Cull, J. P.: Crustal Heat Flow, Cambridge University Press, 324, 2001.

Ben-Zion, Y., Henyey, T. L., Leary, P. C., and Lund, S. P.: Observations and implications of water well and creepmeter anomalies in the Mojave desert of the San Andreas fault zones, BSSA, 80, 1661-1676, 1990.

Bernard, P.: From the search of "precursors" to the research on "crustal transients", Tectonophysics, 338, 225-232, 2001.

Biella, G. C., Gelati, R., Maistrello, M., Mancuso, M., Massiotta, P., and Scarascia, S.: The structure of upper crust in the AlpsApennines boundary region deduced from refraction seismic data, Tectonophysics, 142, 71-85, 1987.

Bortolami, G. C., Di Molfetta, G., Olivero, G. F., Verga, G., and Zuppi, G. M.: Il serbatoio geotermico di Acqui Terme, Energia Geotermica, Prospettive aperte dalle ricerche CNR, Eds. CNR PFE, Pisa, 3, 36 pp., 1982.

Bortolami, G. C., Cravero, M., Olivero, G. F., Ricci, B., and Zuppi, G. M.: Chemical and isotopic measurements of geothermal discharges in the Aqui Terme district, Piemonte, Italy, Geothermics, 12, 2/3, 185-197, 1983.

Bortolami, G. C., Olivero, G. F., and Zuppi, G. M.: Sistemi idrici profondi e freddi, in Piemonte e Valle d'Aosta, Mem. Soc. Geol. It., 29, 171-185, 1984.

Bozzo, E., Campi, S., Capponi, G., and Giglia, G.: The suture between the Alps and Apennines in the Ligurian sector based on geological and geomagnetic data, Tectonophysics, 206, 159-169, 1992.

Brown, A.: Evaluation of possible gas micro-seepage mechanism, AAPG Bull., 184, 11, 1775-1789, 2000.
Brune, J. N., Henyey, T. L., and Roy, R. F.: Heat flow, stress and rate of slip along the San Andreas Fault, J. Geophys. Res., 74, 15, 3821-3827, 1969.

Capasso, G. and Inguaggiato, S.: A simple method for the determination of dissolved gases in natural water. An application to thermal water from Vulcano Island, Applied Geochem., 13, 631642, 1998.

Cassano, E., Anelli, L., Fichera, R., and Cappelli, V.: Pianura Padana. Interpretazione integrata di dati geofisici e geologiche (AGIP), Rapp. Int. AGIP, San Donato Milanese, 27 pp., 1986.

Cassinis, R.: The geophysical exploration of the upper crust from the Ligurian coast to the Northern margin of the Po Valley; problems and results, Tectonophysics, 128, 381-394, 1986.

Catteneo, M., Augliera, P., Spallarossa, D., and Eva, C.: Reconstruction of seismogenic structures by multiples analyses: an example of Western Liguria, BSSA, 87, 971-987, 1997.

Dominco, E., Giraudi, C., Zanella, E., Fancelli, R., Noto, P., and Nuti, S.: Le sorgenti termali del piemonte. Regione Piemonte, Ass. Acque Minerali e Termali, Torino, 1980.

EC Contract ENK6-CT-2000-00056: 3F-CORINTH. Fault Fractures and Fluids, Technical Annex, Bruxelles, Belgium, 42 pp., 1999.

Elter, P. and Pertusati, P.: Considerazioni sul limite Alpi-Appennino e sulle relazioni con l'arco delle Alpi Occidentali, Mem. Soc. Geol. It., 12, 359-376, 1973.

Favara, R., Grassa, F., Madonia, P., and Valenza, M.: Geochemical Processes governing changes in the chemistry of some thermal and cold springs in Central Italy, Proc. WRI-10, Water-Rock interaction X Int. Conference, Villasimius, Italy, June 2001, Balkema Eds., 2, 811-814, 2001a.

Favara, R., Italiano, F., and Martinelli, G.: Earthquake-induced chemical changes in the thermal waters of the Umbria region during the 1997-1998 seismic swarm, Terra Nova, 13, 227-233 2001b.

Galli, G., Mancini, C., Quattrocchi, F., and Sandri, S.: Development of groundwater radon continuous monitors: comparison between $\alpha$ scintillation and $\gamma$ spectrometry systems, Il Nuovo Cimento, 25, 45-55, 2002.

Gelati, R. and Massiotta, P.: Indici geomorfologici di deformazione neo-tettoniche lungo la "Linea Villavernia-Varzi-Bobbio" Appennino settentrionale, Rend. Ist. Lomb. Accad. Sci. Lett., 111, 79-88, 1977.

Geller, R. J., Jackson, D. D., Kagan, Y. Y., and Mulargia, F.: Cannot earthquakes be predicted?, Science, 278, 488-490, 1997.

Geller, R. J.: Earthquake prediction: a critical review, Geophys. J. Int., 131, 425-450, 1997.

Gilman, J. J.: Mechanism of shear-induced metallization, Czech J. Phys, 45, 913-919, 1995.

Gilman, J. J.: Mechanochemistry, Science, 274, 65, 1996.

Goff, F. and Lackner, K. S.: Carbon dioxide sequestering using ultramafic rocks, Environmental Geosciences, 5, 3, 89-101, 1998.

Günther, K. and Reuttern, K. J.: Geotectonic interpretation of geophysical models of the Monferrato area (South-Western Po Plain), in: Alps, Apennines and Hellemides, Scweizerbart, Stuttgart, (Eds) Closs, H., et al., 289-293, 1978.

Gurrieri, S., Hauser, S., and Valenza, M.: Indagine preliminare su alcune sorgenti termali della Calabria per una futura sorveglianza geochimica dell'attivit sismica, in: Risorse termali della Sicilia ed isole minori, Stampatori tipolitografici associati, Palermo, 1984.

Heard, H. C. and Rubey, W. W.: Tectonic implication of Gypsum Dehydration, Am. Bull. Geol. Soc., 77, 741-760, 1966. 
Henyey, T. L. and Wasserburg, G. J.: Heat flow near major strikeslip fault in California, JGR, 76, 7924-7946, 1971.

Hickman, S., Sibson, R., and Bruhn, R.: Introduction to special session: mechanical involvement of fluids in faulting, J. Geophys. Res., 100, 12 831-12 840, 1995.

Igarashi, G., Saeki, S., Takahata, N., Sumikawa, K., Tasaka, S., Sasaki, Y., Takahasashi, M., and Sano, Y.: Groundwater anomaly before the Kobe earthquake in Japan, Science, 269, 60-61, 1995.

Ingebritsen, S. E. and Hayba, D. O.: Fluid flow and heat transport near the critical point of water, Geophys. Res. Lett., 21, 21992203, 1994.

Ingebritsen, S. E. and Sanford, W. E.: Groundwater in geological processes, Cambridge University Press, 1998.

Lachenbruch, A. H.: Crustal temperature and heat productivity: implications of the linear heat flow reactions, 75, 3291-300, 1970.

Lachenbruch, A. H. and Sass, J. H.: Heat flow and energetics of the San Andreas Fault Zone., J. Geophys. Res., 85, 6097-6112, 1980.

Lachenbruch, A. H.: Frictional Heating, fluid pressure and the resistance of fault motion, J. Geophys. Res., 85, 6185-223, 1980.

Lachenbruch, A. H., Sass, J. H., and Morgan, P.: Thermal regime of the Southern Basin and Range Province: 2. Implications of heat flow for regional extension and metamorphic core complex, J. Geophys. Res., 99, B11, 22 121-21 133, 1994.

Laubscher, H. P.: The arcs of the western Alps and Northern Apennines: an updates review, Tectonophysics, 146, 67-78, 1988.

Losecke, W. and Scheelke, I.: Results of magnetotelluric measurements in the South-Western Po Plain, in: Alps, Apennines and Hellemides, Scweizerbart, Stuttgart, (Eds) Closs, H., et al., 228230, 1978.

MacDonald, G. J. F.: Anhydrite-gypsum equilibrium relationships, Am. J. Sci., 251, 884-898, 1953.

Mancini, C., Quattrocchi, F., Guadoni, C., Pizzino, L., and Porfidia, B.: ${ }^{222} \mathrm{Rn}$ study throughout different seismotectonical areas: comparison between different techniques for discrete monitoring, Annali di Geofisica, 43, 1, 31-60, 2000.

Marini, L., Bonaria, V., Guidi, M., Hunziker, J. C., Ottonello, G., and Zuccolini, M. V.: Fluid geochemestry of the Acqui Terme - Visone geothermal area (Piemonte, Italy), Applied Geochemistry, 15, 917-935, 2000.

Massa, M., Eva, E., Marasca, P., and Spallarossa, D.: Are the two earthquake sequences in the monferrato area (Southern Piemonte, Italy) originated by the same structure?, Proc. ESC XXVIII General Assembly, Genoa 2002, p. 84, 2002.

Miletto, M. and Polino, R.: A gravity model of the crust beneath the Tertiary Piemonte Basin (NorthWestern Italy), Tectonophysics, 212, 243-256, 1992.

Molnar, P. and England, P.: Temperaures, heat flow and frictional stress near major thrust faults, J. Geophys. Res., 95, B4, 48334856, 1990.

Nur, A. and Walder, J.: Hydraulic Pulses in the earth's crust, in: Fault mechanics and transport properties of rocks, (Eds) Academic Press, 530, 461-473, 1992.

Quattrocchi, F., Guerra, M., Pizzino, L., and Lombardi, S.: Radon and helium as pathfinders of fault systems and groundwater evolution in different Italian areas, Il Nuovo Cimento, 22, 3/4, 309316, 1999.

Quattrocchi, F.: In search of evidences of deep fluid discharges and pore pressure evolution in the crust to explain the seismicity style of Umbria-Marche 1997-1998 seismic sequence (Central Italy), Ann. Geof., 42, 4, 1-29, 1999.

Quattrocchi, F., Pik, R., Angelone, M., Barbieri, M., Conti, M.,
Guerra, M., Lombardi, S., Marty, B., Pizzino, L., Sacchi, E., Scarlato, P., and Zuppi, G. M.: Geochemical changes at the Bagni di Triponzo thermal spring, during the Umbria-Marche 1997-1998 seismic sequence, J. of Seismology, 4, 567-587, 2000a.

Quattrocchi, F., Di Stefano, G., Pizzino, L., Pongetti, F., Romeo, G., Scarlato, P., Sciacca, U., and Urbini, G.: The Geochemical Monitoring System II prototype (GMS II) installation at the Acqua Difesa well, within the Etna region. first data during the 1999 volcanic crisis, JVGR, 101, 273-306, 2000b.

Quattrocchi, F., Galli, G., and Pizzino, L.: Fluid geochemistry along the Heliki and Aigion seismogenic segments (Greece), Proc. EGS General Assembly, Nice, March 2001, Abstract, 2001.

Ramsberg, H.: Temperature changes associated with adiabatic decompression in geological processes, Nature, 234, 539-540, 1971.

Roeloff, E. A.: Hydrologic precursors to earthquakes: a review, Pageoph, 126, 177-209, 1988.

Salvi, S., Quattrocchi, F., Angelone, M., Brunori, C. A., Billi, A., Buongiorno, F., Doumaz, F., Funiciello, R., Guerra, M., Lombardi, S., Mele, G., Pizzino, L., and Salvini, F.: A multidisciplinary approach to earthquake research: implementation of a Geochemical Geographic Information System for the Gargano site, Southern Italy, Natural Hazard, 20, 1, 255-278, 2000.

Scholz, C. H., Beavan, J., and Hanks, T. C.: Frictional metamorphism, argon depletion and tectonic stress on the Alpine Fault, New Zealand, J. Geophys. Res., 84, 6770-6782, 1979.

Scholz, C. H.: Shear Heating and state of stress on faults, J. Geophys. Res., 85, 6174-6184, 1980.

Sibson, R. H., McM. Moore, J., and Rankin, A. H.: Seismic pumping - a hydrothermal fluid transport mechanism, J. Geol. Soc. London, 131, 653-659, 1975.

Sibson, R. H.: Power dissipation and stress levels on faults in the upper crust, J. Geophys. Res., 85, 6239-6247, 1980.

Sibson, R. H.: Fault zones models, heat flow, and the depth distribution of earthquakes in the continental crust of the United States, Bull. Seism. Soc. Am., 72, 151-163, 1982a.

Sibson, R. H.: Implications of fault-valve behaviour for rupture nucleation and recurrence, Tectonophysics, 211, 283-293, 1982b.

Smith, L. and Chapman, D. S.: On the thermal effects of groundwater flow. 1 Regional Scale Systems, J. Geophys. Res., 88, 593$608,1983$.

Sornette, D.: Towards a trully interdisciplinary approach to earthquake prediction, Nature, Web-page: debate, 1999.

Sornette, D.: Mechanochemistry: a hypothesis for shallow earthquakes, in: Earthquake Thermodynamics and phase transformations in the earth's interior, (Eds) Teisseyre R. and Majewski E., Academic Press, 673 pp., 329-366, 2001.

Sturani, C.: Messinian facies in the Piedmont Basin, Mem. Soc Geol. It., 16, 11-25, 1975.

Teisseyre, R. and Majewski, E.: Earthquake Thermodynamics and phase transformations in the earth's interior, Academic Press, 673 pp., 2001

Toutain, J. P. and Baubron, J. C.: Gas Geochemistry and seismotectonics: a review, Tectonophysics, 304, 1-27, 1999.

Thomas, D.: Geochemical precursors to seismic Activity, Pageoph, 126, 241-266, 1988.

Waldaum, D. R.: Temperature changes associated with adiabatic decompression in geological processes, Nature, 232, 545-547, 1971.

Wood, S. A. and Spera, F. J.: Adiabatic decompression of aqueous solutions: applications to hydrothermal fluid migration in 
F. Quattrocchi et al.: Thermal anomalies and fluid geochemistry framework

the crust, Geology, 12, 707-710, 1984.

Wyss, M.: Cannot earthquakes be predicted?, Science, 278, 487488, 1997.

Zanzari, A., Cioni, R., Galli, G., Guidi, M., Mancini, C., Mar- tinelli, A., and Quattrocchi, F.: Discrete and continuous monitoring of groundwater in the Umbrian seismic area, Proc. WRI10, Water-Rock interaction X Int. Conference, Villasimius, Italy, June 2001, Balkema Eds., 1, 110-114, 2001. 